apical and anteapical areoles. Veins white, claval suture brownish. Face and legs tinged with greenish, some of the white tibial spines brown tipped. Tarsal joints at apices dark. Dorsal abdominal segments except lateral and apical margins blackish.

Described from a single male taken at San Augustine (Ckll. 2140).* In form, this insect very closely resembles $P$. superbus and in structure is strictly congeneric with it. It differs very widely, however (and this is a generic difference according to Van Duzee's synoptic table of the genera), in that it does not possess the elytral reticulations or other markings so characteristic of the genus. On a very superficial examination it might be taken for a Chlorotettix, but its general form, stronger build, and lengthened vertex are strictly Phlepsiid.

\title{
ViI. The Grape-Vine Typhlocybids of the Mesilla Valley, N. M.
}

At Las Cruces and Mesilla, N. M., the grape-vine suffers, as in other parts of the U.S., from the attacks of small Typhlocybidae, in most seasons not seriously destructive, but occasionally very abundant and troublesome. Two species are found on the Mission Grape (Vitis vinifera) at Las Cruces in about equal numbers, often on the same leaves. After making a slight study of them, I determined that they were different from the eastern forms, and apparently undescribed. This October I collected a number and sent them to Prof. Gillette, who reports that one is Typhlocyba coloradensis (Gill.), hitherto only recorded from Colorado, but perhaps properly regarded as a variety of $T$. comes Say. The other is a new species of Dicraneura, described below. The genus, Prof. Gillette says, has only two hithertodescribed species in U.S., one of these being not from the U.S. proper, but from Alaska. T. D. A. Ckll.

Dicraneura cockerellii, n. sp. General color light straw yellow, a bright red band crossing the elytra before the middle; length, $3 \mathrm{~mm}$.

Head - Vertex strongly produced and almost acute in front, the angle being somewhat less than a right angle, as long as the

* San Augustine is a branch on the east side of the Organ Mts. All the species above described were taken on Aug. 28, 1894. pronotum; color straw-yellow without distinct markings, in some specimens washed with dilute sanguineous with light spots on the posterior margin next the eyes. Pronotum: The breadth is twice the length, moderately concave behind, color like that of the vertex and, when washed with sanguineous, there is a distinct whitish spot on the middle of the anterior margin next the vertex. Scutellum without distinct markings

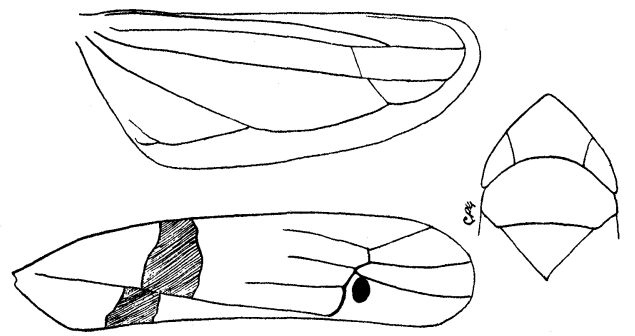

Fig. 4. Dicraneura cockerellii $\times 20$.

and agreeing with the vertex and pronotum in color. Elytra pale straw yellow crossed by a narrow band of bright cherry red varying some in depth of color but plainly discernable in all mature specimens. The band crosses just before the middle of the clavus, and that portion of the band that is above the claval suture is pushed forward so that only about half of its width comes against that portion which is upon the corium; just beyond the cross nervures is a jet black spot lying in the 
inner apical cell. The venation of the wing is peculiar in that the posterior apical cell is very small. All beneath pale yellow. Described from 25 specimens, male and female, sent me by Prof. T. D. A. Cockerell who took them at Las Cruces, N. M.
This is one of the most beautiful Typhlocybids that I have ever seen and I take pleasure in dedicating it to its discoverer.

Agr. College, Ft. Collins, Colo.
C. P. Gillette.

\section{Some New Insects.}

\section{BY T. D. A. COCKERELL.}

\section{Coccide.}

Crypticerya, n. subg.- Similar to Icerya s. str., but not forming an ovisac, and without the waxy tufts of subg. Crossotosoma. Adapted for living under bark. Type, Icerya rose Riley \& Howard.

Proticerya, n. subg.-Similar to Icerya s. str., but adult $q$ with only 9-jointed antennae. Ovisac large. No conspicuous waxy tufts. Type, Icerya rileyi, n. sp.

Icerya rileyi, n. sp. $-q$ dull red, covered with white and yellowish mealy powder, a few small easily deciduous lateral waxy tufts. Ovisac Io $\mathrm{mm}$. long, 5 broad, white with a slight yellowish tinge, smooth, not fluted, obscurely longitudinally grooved beneath. Antennal formula of a specimen from Mesquite, 9 (35) 2I (46) (78), of one from Larrea, 932 I $(4578) 6$. These differences are not specific, the antennae are variable. Legs and antennae black. For the $\delta$ and larval characters see Canad. Entomologist, 1894, p. 34. No further description is given at this time, as it is hoped to describe and figure the various stages from fresh material hereafter. The insect will be very easily recognized by the characters now cited, especially if reference is also made to the descriptive notes of Prof. Townsend, Bull. 7, N. M. Agr. Exp. Sta., p. I5.

Hab.-- Las Cruces, N. M., common on Mesquite (Prosopis) and rather rare on Creosote bush (Larrea). It is attacked by
Laetilia and an apparently new species of Coccinellidae. This interesting species was to have been described by Dr. Riley had he lived; in his opinion, it represented a valid new genus. The ant, Dorymyrmex pyramicus Rog., attends it.

Aspidiotus prosopidis, n. sp. $-q$ scale about $\frac{1}{2} \mathrm{~mm}$. diameter; slightly convex, from circular to very broad pyriform, slightly shining, pitch black; exuviae large, uncovered, ridged, black or slightly greenish or brownish, central. The exuviae are remarkably large for the size of the scale. Removed from the bark the scales leave a broad whitish ring, with no black ring.

$\delta$ scale oval, larger than that of the $q$, white, with yellowish exuviae towards one end. The $\delta$ scales are not ridged, and are of the same texture as those of the $q$.

o extremely small, after boiling in soda transparent, tinged with yellowish-brown, circular in outline, not visibly segmented, anterior end with a large rounded protuberance such as is seen in $A$. personatus. Mouth-parts well-developed. Skin of anterior portion transversely reticulately wrinkled. No grouped ventral glands. Lobes extremely small, two pairs, median rounded, nearly as far apart as the diameter of one. Second lobes also rounded; but broader and lower than the median, nearly as far from them as the diameter of one. A spine close to each lobe, and three on the margin beyond, at long intervals. 

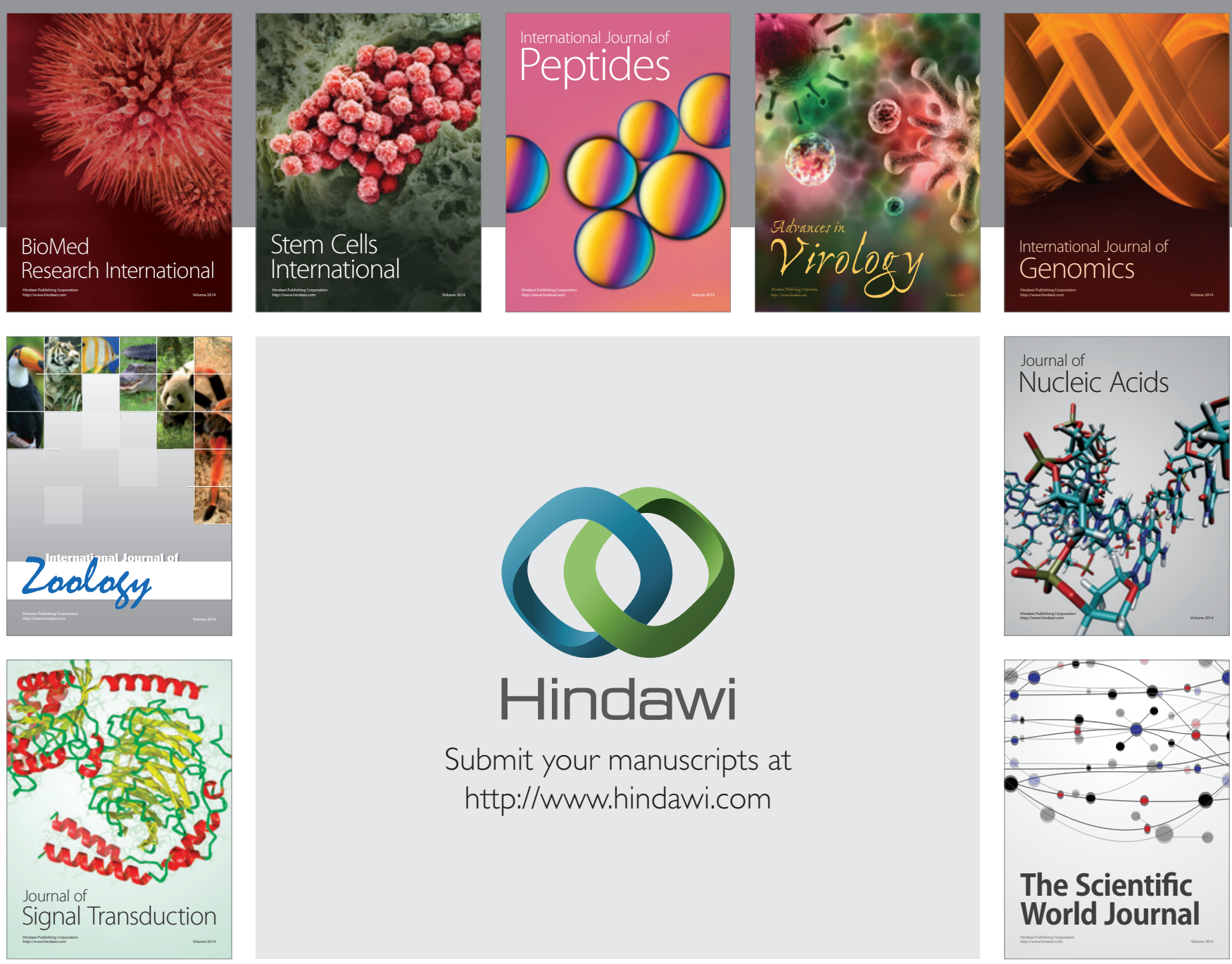

Submit your manuscripts at

http://www.hindawi.com
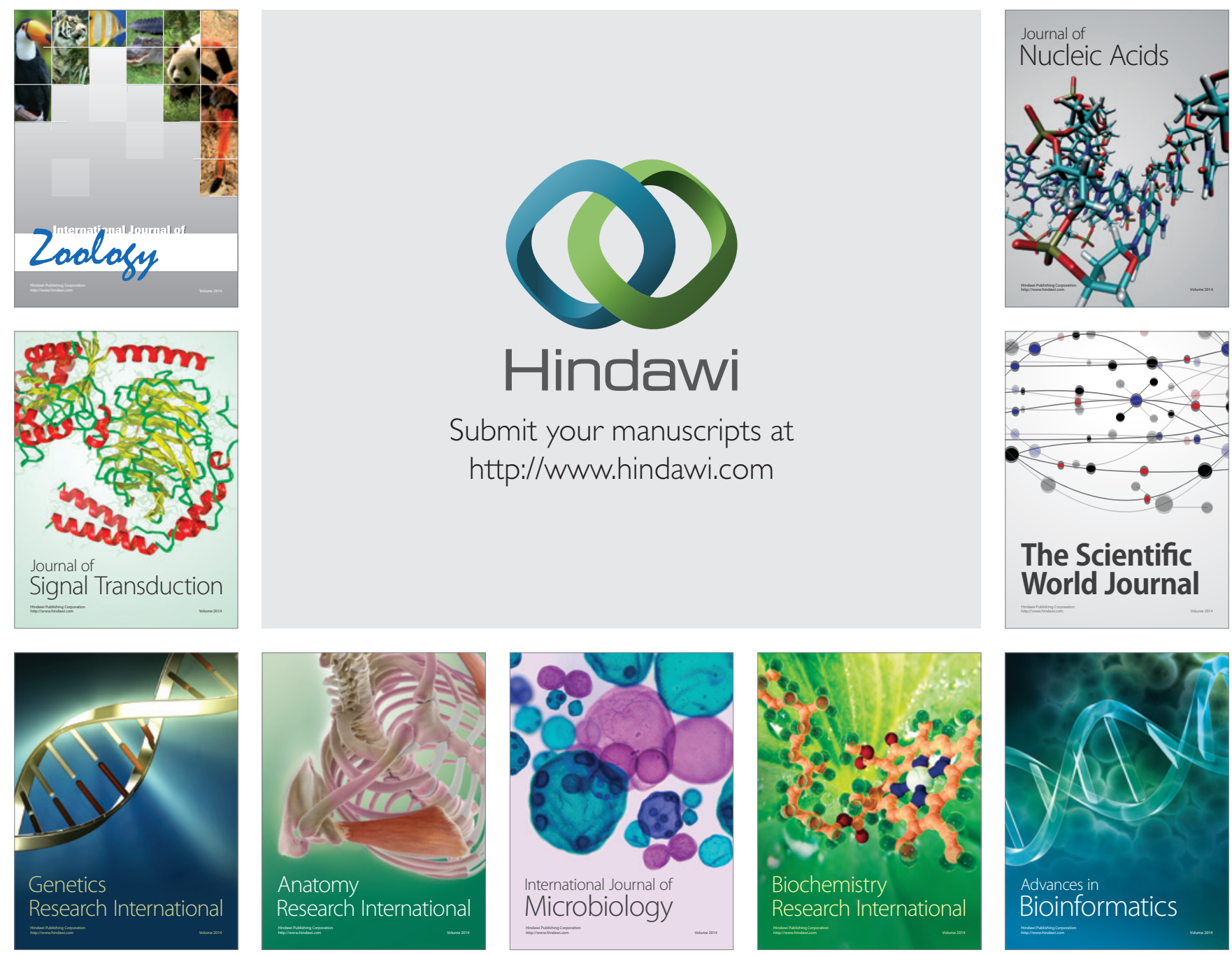

The Scientific World Journal
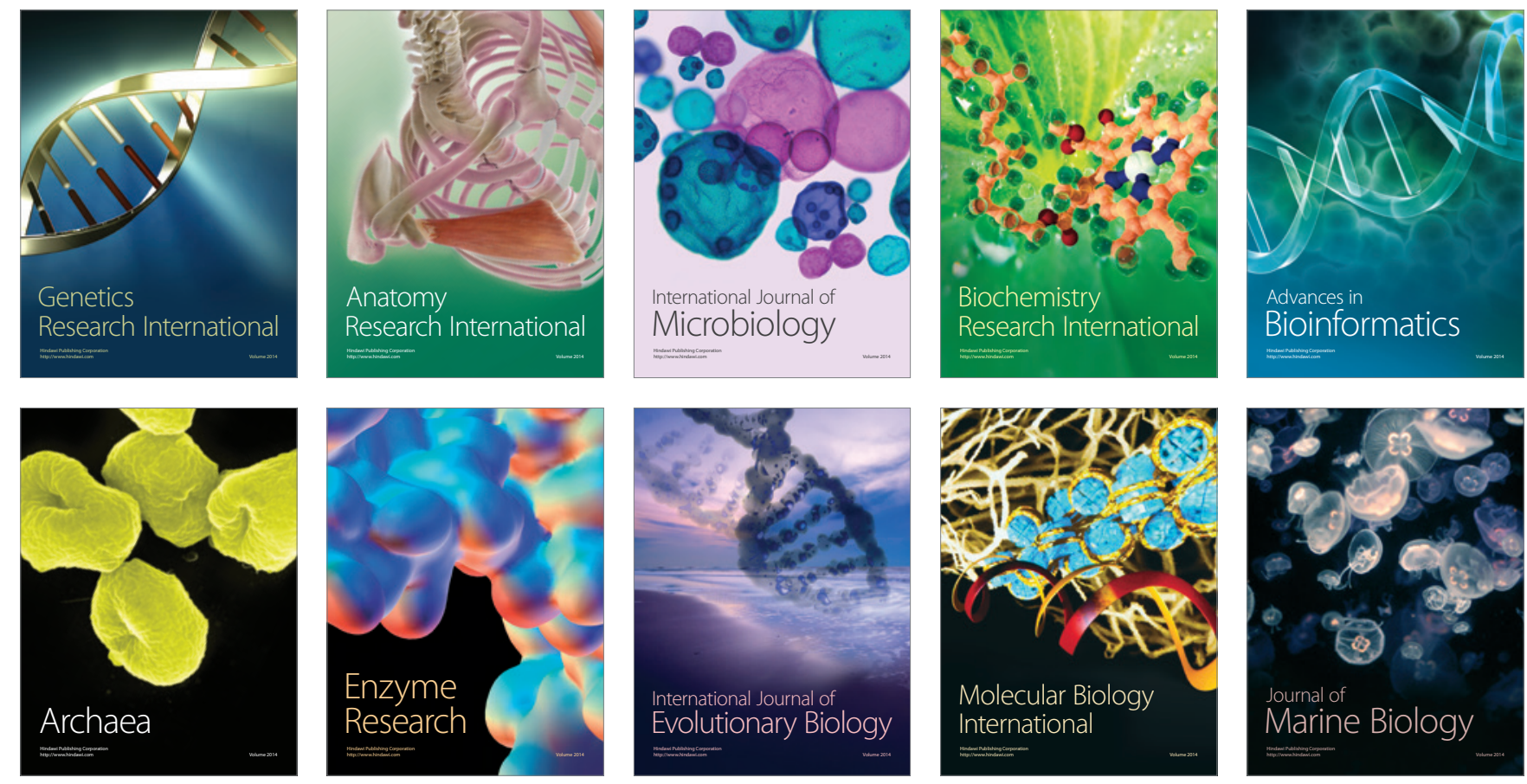